PEMBELAJAR: Jurnal Ilmu Pendidikan, Keguruan, dan Pembelajaran

Volume 1 Nomor 1 April 2017 hal 17-24

e-ISSN: 2549-9114 dan p-ISSN: 2549-9203

(Received: Januari-2017; Reviewed: Maret-2017; Published: April 2017)

\title{
Efektivitas Metode Discovery Learning Berbantuan E-Learning di SMA Negeri 1 Jepara
}

\author{
${ }^{1}$ Ninok Eyiz Sumianingrum, ${ }^{2}$ Hari Wibawanto, ${ }^{3}$ Haryono \\ ${ }^{1,2,3}$ Prodi Kurikulum dan Teknologi Pembelajaran, \\ Program Pascasarjana, Universitas Negeri Semarang, Indonesia \\ Email: ninok@smansara.com
}

\begin{abstract}
Abstrak: Tujuan penelitian ini untuk mengetahui hasil belajar menggunakan metode Discovery Learning berbantuan aplikasi E-Learning Edmodo, menganalisis perbedaan hasil belajar peserta didik menggunakan metode Discovery Learning berbantuan aplikasi E-Learning Edmodo dengan Discovery Learning berbantuan aplikasi presentasi, menganalisis perbedaan hasil belajar peserta didik laki-laki dengan perempuan, dan menganalisis hubungan antara metode Discovery Learning berbantuan aplikasi E-Learning Edmodo dengan hasil belajar peserta didik laki-laki dan perempuan kelas $\mathrm{X}$ SMAN 1 Jepara. Jenis penelitian yang digunakan adalah Quasi Experiment menggunakan desain faktorial (2x2). Analisis data yang digunakan adalah (1) analisis deskriptif untuk mengetahui rata-rata nilai sikap spiritual, sikap sosial, proyek, produk, dan respon peserta didik, dan (2) analisis inferensial menggunakan analisis Two Way Anova untuk menguji hipotesis perlakuan perbedaan hasil belajar peserta didik laki-laki dan perempuan menggunakan Discovery Learning berbantuan aplikasi. Hasil penelitian menunjukkan bahwa: (1) Pembelajaran dengan metode Discovery Learning berbantuan aplikasi E-Learning Edmodo memuat 6 langkah-langkah, (2) Terdapat perbedaan hasil belajar peserta didik yang menggunakan Discovery Learning berbantuan aplikasi E-Learning Edmodo dengan Discovery Learning berbantuan aplikasi presentasi, (3) Terdapat perbedaan hasil belajar peserta didik laki-laki dengan perempuan, dan (4) Tidak ada hubungan antara metode Discovery Learning berbantuan aplikasi terhadap hasil belajar peserta didik laki-laki dan perempuan kelas X SMAN 1 Jepara.
\end{abstract}

Kata Kunci: Efektivitas, Discovery Learning, E-Learning, Edmodo

\begin{abstract}
The research aims is to determine learning outcomes using the Discovery Learning methods in Edmodo Learning Management System, analyze the differences in learning outcomes of students using the Discovery Learning using Edmodo Learning Management with Discovery Learning aided by presentation applications, analyze the differences in learning outcomes of male and female students, and analyze the relationship between the Discovery Learning methods using Edmodo with the learning outcome of male and female students grade X SMAN 1 Jepara. Research conducted in a Quasi Experiment using a factorial design (2x2). Analysis of the data were used: (1) descriptive analysis to determine the average value of spiritual attitudes, social attitudes, projects, products, and response learners, and (2) inferential analysis using analysis Two Way ANOVA to test the hypothesis of treatment differences in learning outcomes of male and female student. The results showed that: (1) Discovery Learning methods using Edmodo contains six steps, (2) There are differences in learning outcomes of students who use the Discovery Learning methods by Edmodo with Discovery Learning aided by presentation applications (3) there are differences in learning outcomes of male and female students, and (4) there is no relationship between the method of Discovery learning aided application to the learning outcome of male and female students grade X SMAN 1 Jepara.
\end{abstract}

Keywords: Learning Effectiveness, Discovery Learning, E-Learning, Edmodo 


\section{PENDAHULUAN}

Proses pembelajaran Kurikulum 2013 mensyaratkan keaktifan peserta didik dan berubahnya paradigma dari pembelajaran berpusat pada guru menjadi pembelajaran berpusat pada peserta didik. Hasil belajar peserta didik kelas X SMAN 1 Jepara belum memenuhi harapan yang diinginkan. Sebanyak $52,77 \%$ peserta didik pada mata pelajaran Prakarya dan Kewirausahaan memerlukan remedial untuk memperbaiki nilai agar mencukupi Kriteria Ketuntasan Minimal (KKM). Perlu adanya upaya untuk memperbaiki kegiatan belajar mengajar yang lebih menekankan pada perkembangan kemampuan berpikir peserta didik, salah satunya menggunakan Discovery Learning (DL), yang akan membantu peserta didik belajar untuk diri mereka sendiri dan menerapkan pengetahuan apapun di lingkungan yang baru, yang pada akhirnya akan mencapai pembelajaran yang efektif (Mahmoud, 2014). Metode DL sering dikaitkan dengan Jerome Bruner yang berpendapat bahwa proses menemukan oleh diri sendiri akan mengajarkan seseorang untuk memperoleh informasi dengan cara membuat informasi tersebut lebih mudah ditemukan pemecahan masalahnya (Bruner, 1961: 26). Pada jenjang pendidikan menengah, DL juga efektif membantu peserta didik memahami konsep-konsep yang sulit dan menyimpan informasi jangka panjang (McDonald: 2011). Penerapan DL berbantuan Teknologi Informasi dan Komunikasi (TIK) saat ini merupakan keniscayaan. Sebuah penelitian menunjukkan bahwa pembelajaran dalam jaringan (daring) berkontribusi pada aspek pembelajaran konstruktivisme dan observasional, yang membuat peserta didik dapat memperluas pengetahuan mereka di luar kelas dengan melakukan percobaan dan penyelidikan secara mandiri (Siemens dan Tittenberger, 2009:18-19). Dalam hal ini, mereka dapat memanfaatkan aplikasi daring selain media sosial. Manfaat utama media sosial di Learning Management System (LMS), yang fitur teknis utamanya terdiri dari sharing, pengelompokan, percakapan dan keterhubungan ( $\mathrm{Hu}$ dan Gollin, 2010) adalah sebagai penggerak motivasi belajar (Mbati, 2013: 181). Ketersediaan sarana dan prasarana TIK yang memadai memperkuat perlunya penggunaan E-Learning, salah satunya Edmodo, untuk digunakan dalam pembelajaran.
Edmodo memungkinkan untuk 1) memfasilitasi dan menginspirasi belajar peserta didik, seperti mengunggah video pembacaan puisi di YouTube, 2) merancang pengalaman dan penilaian belajar di era digital dan 3) menciptakan permodelan pembelajaran di era digital (Lie, 2013). Guru yang menggunakan pembelajaran yang mengintegrasikan tatap muka dan pembelajaran daring, blended learning, disarankan agar tidak hanya menilai kinerja peserta didik melalui tes saja, tetapi juga menggunakan penilaian diri, sehingga kinerja pembelajaran peserta didik dapat dinilai secara obyektif dan subyektif (Chang dkk, 2014: 226).

Tujuan penelitian ini adalah (1) Untuk mengetahui pelaksanaan pembelajaran dengan menggunakan metode Discovery Learning berbantuan aplikasi E-Learning Edmodo pada peserta didik kelas X SMAN 1 Jepara, (2) Untuk menganalisis perbedaan hasil belajar peserta didik yang menggunakan metode Discovery Learning berbantuan aplikasi E-Learning Edmodo dengan metode Discovery Learning tanpa bantuan aplikasi video di kelas X SMAN 1 Jepara, (3) Untuk menganalisis perbedaan hasil belajar peserta didik antara yang berjenis kelamin laki-laki dengan berjenis kelamin perempuan di kelas X SMAN 1 Jepara, dan (4) Untuk menganalisis interaksi antara metode Discovery Learning berbantuan aplikasi ELearning Edmodo dengan jenis kelamin terhadap hasil belajar peserta didik kelas $\mathrm{X}$ SMAN 1 Jepara.

\section{METODE PENELITIAN}

Metode yang digunakan adalah Quasi Experiment, suatu desain eksperimen yang memungkinkan peneliti mengendalikan variabel sebanyak mungkin dari situasi yang ada. Pengumpulan data dilakukan melalui angket lembar observasi dan tes hasil belajar. Angket digunakan untuk mengetahui nilai sikap spiritual dan respon peserta didik yang dianalisis menggunakan skala Likert. Sedangkan lembar observasi digunakan untuk memperoleh data nilai sikap sosial, dan nilai produk peserta didik. Observasi dilakukan secara langsung terhadap peserta didik selama melaksanakan pembelajaran dengan menggunakan pedoman observasi yang memuat format penilaian dan kriteria-kriteria sikap sosial dan unjuk kerja yang akan diamati.

Penelitian menggunakan desain faktorial (2 x 2) dengan faktor utama metode Discovery 
Learning (A) dengan ukuran $\mathrm{A}=1$ berbantuan aplikasi E-Learning Edmodo dan $\mathrm{A}=2$ tanpa aplikasi E-Learning Edmodo, serta jenis kelamin (B) dengan ukuran $\mathrm{B}=1$ laki-laki dan $\mathrm{B}=2$ perempuan. Analisis ini digunakan untuk menguji hipotesis metode Discovery Learning berbantuan aplikasi dan jenis kelamin serta interaksi keduanya.

Tabel 3.1. Desain Perlakuan Antara Faktor A dan B

\begin{tabular}{ccc}
$\begin{array}{c}\text { Variabel A } \\
\text { VariabetB }\end{array}$ & $\mathrm{A}=1$ & $\mathrm{~A}=2$ \\
\hline $\mathrm{B}=1$ & $\mathrm{Y}_{11}$ & $\mathrm{Y}_{12}$ \\
\hline $\mathrm{B}=2$ & $\mathrm{Y}_{21}$ & $\mathrm{Y}_{22}$
\end{tabular}

(Supardi, 2013: 350)

Keterangan :

$\mathrm{A}=\mathrm{A}=1$ berbantuan aplikasi E-Learning Edmodo; $\mathrm{A}=2$ berbantuan aplikasi presentasi.

$\mathrm{B}=\mathrm{B}=1$ laki-laki; $\mathrm{B}=2$ perempuan.

Y11 = Rata-rata hasil belajar laki-laki dengan Discovery Learning berbantuan aplikasi E-Learning Edmodo.

Y12 = Rata-rata hasil belajar laki-laki dengan Discovery Learning berbantuan aplikasi presentasi.

Y21 = Rata-rata hasil belajar peserta didik perempuan dengan Discovery Learning berbantuan aplikasi E-Learning Edmodo.

Y22 = Rata-rata hasil belajar peserta didik perempuan dengan Discovery Learning berbantuan aplikasi presentasi.

Eksperimen dilakukan terhadap proses pembelajaran Discovery Learning berbantuan aplikasi E-learning Edmodo dan berbantuan aplikasi presentasi baik pada peserta didik lakilaki maupun perempuan. Dalam penelitian ini materi ajar yang dibuat diintegrasikan di aplikasi E-learning Edmodo. Topik materi yang digunakan dalam penelitian ini adalah Membuat Produk Kerajinan Tekstil. Kompetensi Dasar materi tersebut adalah memahami sumber daya yang dibutuhkan dalam mendukung proses produksi kerajinan limbah tekstil dan membuat karya kerajinan limbah tekstil yang berkembang di wilayah setempat dan lainnya sesuai teknik dan prosedur.

\section{HASIL DAN PEMBAHASAN}

Hasil analisis menggunakan $\mathrm{Uji} T$ menunjukkan bahwa rata-rata skor spiritual peserta didik yang mendapatkan pembelajaran Discovery Learning berbantuan aplikasi $E$ Learning Edmodo baik yang berjenis kelamin laki-laki maupun perempuan lebih tinggi dari pada rata-rata skor spiritual peserta didik lakilaki maupun perempuan yang mendapatkan metode Discovery Learning berbantuan aplikasi presentasi seperti tampak pada Gambar 1 di bawah ini. Data ini mengindikasikan terdapat pengaruh yang baik penggunaan metode Discovery Learning berbantuan aplikasi $E$ Learning Edmodo terhadap perkembangan sikap spiritual peserta didik.

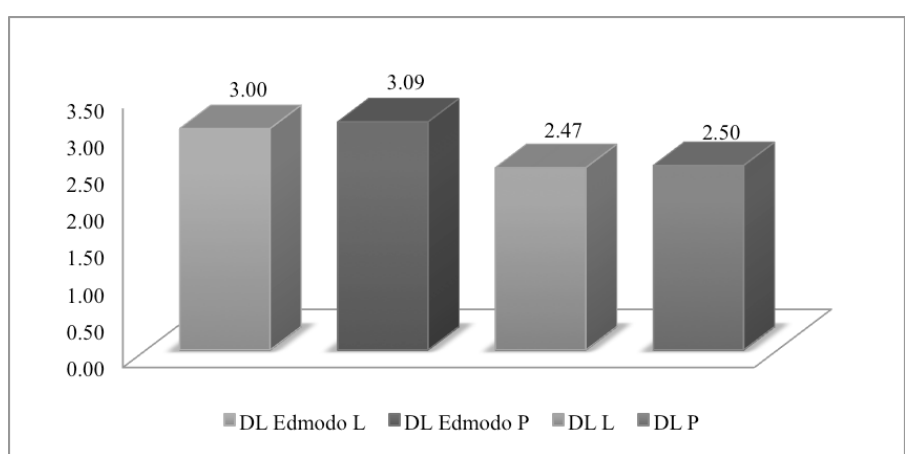

Gambar 1. Hasil Sikap Spiritual Peserta didik Setiap Kelas

Skor sikap sosial peserta didik yang terlihat pada Gambar 2 di bawah menunjukkan bahwa peserta didik laki-laki maupun perempuan yang mendapatkan pembelajaran Discovery Learning berbantuan aplikasi $E$ Learning Edmodo lebih tinggi dibandingkan dengan yang mendapatkan pembelajaran Discovery Learning berbantuan aplikasi presentasi ditinjau dari aspek percaya diri, kreatif, tekun, jujur, pantang menyerah, dan kerjasama. Kondisi ini merupakan suatu pertanda dalam bahwa penggunaan metode Discovery Learning berbantuan aplikasi $E$ Learning Edmodo berpengaruh dengan baik terhadap perkembangan sikap sosial peserta didik. 


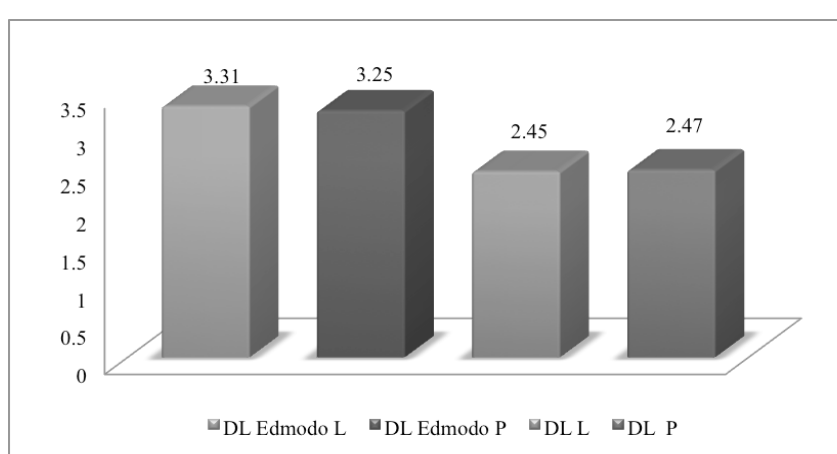

Gambar 2. Hasil Sikap Sosial Peserta didik Setiap Kelas

Hasil uji $\mathrm{T}$ menunjukkan rata-rata skor penilaian produk peserta didik pada Gambar 3 di bawah menunjukkan bahwa hanya peserta didik laki-laki maupun perempuan yang mendapatkan pembelajaran Discovery Learning berbantuan aplikasi E-Learning Edmodo memiliki rata-rata skor lebih tinggi dibandingkan dengan yang mendapatkan pembelajaran Discovery Learning berbantuan aplikasi presentasi ditinjau dari aspek tahapan perencanaan alat dan bahan, tahap proses pembuatan, dan hasil produk.

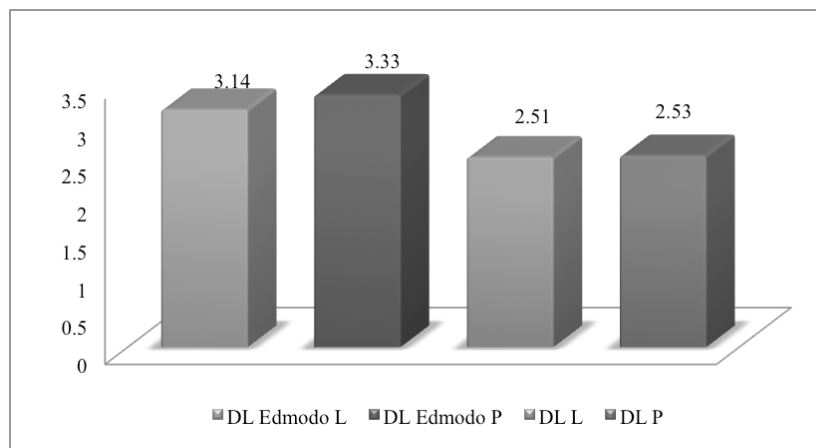

Gambar 3. Hasil Penilaian Produk Peserta didik Setiap Kelas

Hasil tes hasil belajar seperti ditunjukkan pada Gambar 4 menunjukkan bahwa peserta didik laki-laki maupun perempuan yang mendapatkan pembelajaran Discovery Learning berbantuan aplikasi $E$ Learning Edmodo memperoleh rata-rata hasil belajar yang lebih tinggi daripada yang mendapatkan Discovery Learning berbantuan aplikasi presentasi. Hasil ini mengindikasikan bahwa peserta didik yang menggunakan Discovery Learning berbantuan aplikasi $E$ Learning Edmodo memperoleh manfaat lebih banyak sehingga dapat mencapai ketuntasan belajar peserta didik pada materi Karya Kerajinan Limbah Tekstil di kelas X SMA Negeri 1 Jepara.

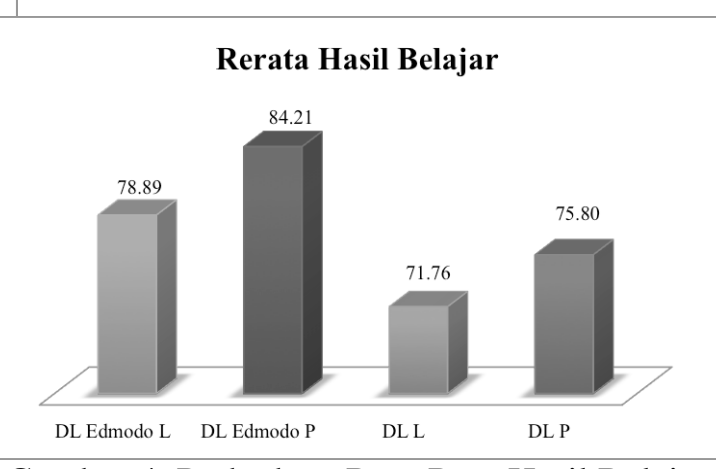

Gambar 4. Perbedaan Rata-Rata Hasil Belajar

Pembelajaran Discovery Learning (DL) mengacu pada tiga ciri utama belajar dengan cara menemukan, yaitu: (1) mengeksplorasi dan memecahkan masalah untuk menciptakan, menggabungkan dan menggeneralisasikan pengetahuan, (2) berpusat pada peserta didik, (3) kegiatan untuk menggabungkan pengetahuan baru dan pengetahuan yang sudah ada. DL yang yang menggunakan E-Learning akan membuat pembelajaran semakin lebih baik dan menarik. Pengemasan pembelajaran DL berbantuan aplikasi E-Learning Edmodo memuat langkahlangkah (1) Stimulus, yakni peserta didik diberikan sejumlah permasalahan untuk merangsang berpikir peserta didik, menumbuhkan rasa ingin tahu peserta didik yang mengarah pada persiapan pemecahan masalah. (2) Problem Statement, yakni peserta didik diberikan kebebasan berpikir untuk mengidentifikasi masalah yang relevan dengan bahan pelajaran, kemudian dirumuskan dalam bentuk hipotesis. (3) Data collection, yakni peserta didik diberikan kesempatan mengumpulkan informasi yang relevan baik melalui pengamatan ataupun membaca sumber belajar untuk membuktikan benar tidaknya hipotesis tersebut. (4) Data Prosessing, yakni peserta didik diberikan kesempatan untuk mengolah hasil temuannya, dengan membandingkan hipotesis yang telah dirumuskan. (5) Verifikasi, yakni peserta didik melakukan pemeriksaan secara cermat baik melalui diskusi maupun tanya jawab untuk membuktikan benar atau tidaknya hipotesis dan mampu menemukan konsep dari materi pelajaran. (6) Generalisasi, yaitu peserta didik bersama-sama menarik kesimpulan yang dapat dijadikan prinsip bersama-sama melakukan penarikan umum dan berlaku untuk semua kejadian atau permasalahan yang sama.

Proses yang terjadi dalam pembelajaran 
Discovery Learning berbantuan aplikasi ELearning Edmodo memunculkan perilaku tersendiri pada diri peserta didik, yang sebelumnya pasif dalam mengikuti pembelajaran berubah menjadi aktif. Penggunaan Discovery Learning berbantuan aplikasi E-Learning Edmodo membawa perubahan dalam perkembangan pembelajaran peserta didik. Guru juga merasa terbangkitkan semangat mengajarnya yang sebelumnya telah turun. Adanya kombinasi metode pembelajaran dengan E-Learning juga ditekankan oleh Khan (2014) yang mengungkapkan perlunya memperkenalkan kontrol untuk lebih memahami dampak penggunaan E-Learning dan Discovery Learning. Pada saat guru tidak menggunakan alat-alat yang diusulkan, tingkat kegagalan justru meningkat secara dramatis. Praktik pembelajaran inovatif jika dilakukan secara terstruktur dan dibantu oleh Blended Learning, dapat meningkatkan pembelajaran peserta didik dan mengurangi tingkat kegagalan secara keseluruhan.

Salah satu media yang mampu memberikan suasana berbeda dan bervariasi adalah media pembelajaran E-Learning berbantuan aplikasi Edmodo. Pelaksanaan pembelajaran dengan metode pembelajaran Discovery Learning berbantuan aplikasi pada awalnya mengalami sedikit hambatan. Tetapi hambatan-hambatan yang terjadi perlahan dapat dikurangi karena partisipasi aktif peserta didik dalam proses pembelajaran. Aktivitas di dalam kelas yang bervariatif dapat menambah semangat, motivasi, karakter berbagi, membantu dalam memecahkan masalah dan dapat menciptakan lingkungan belajar positif, sehingga pembelajaran menjadi lebih interaktif dan efektif.

Hasil analisis ketuntasan belajar peserta didik menunjukkan bahwa peserta didik yang dapat tuntas dalam belajar pada mata pelajaran Prakarya dan Kewirausahaan jika menggunakan metode Discovery Learning berbantuan aplikasi E-Learning Edmodo. Sedangkan jika menggunakan pembelajaran dengan metode Discovery Learning berbantuan aplikasi presentasi maka ketuntasan belajar peserta didik tidak dapat dicapai dengan baik. Rata-rata hasil belajar antara setiap kelompok juga menunjukkan terdapat perbedaan hasil belajar dengan hasil belajar peserta didik yang mendapatkan pembelajaran dengan menggunakan metode Discovery Learning berbantuan aplikasi E-Learning Edmodo lebih tinggi daripada rata-rata hasil belajar peserta didik yang menggunakan metode Discovery Learning berbantuan aplikasi presentasi. Hasil ini sejalan dengan hasil penelitian yang dilakukan oleh Suriadhi, Tastra, dan Suwatra (2014) yang mengungkapkan bahwa penggunaan E-Learning berbasis Edmodo efektif untuk meningkatkan hasil belajar IPA pada peserta didik kelas VIII di SMP Negeri 2 Singaraja.

Perbedaan hasil belajar dikarenakan metode Discovery Learning berbantuan aplikasi E-Learning Edmodo membuat suasana belajar di kelas menjadi lebih kondusif, aktif dan minat serta antusias peserta didik sangat terlihat jika dibandingkan metode Discovery Learning berbantuan aplikasi presentasi. Pengunaan Edmodo menjadikan distribusi materi pembelajaran yang tidak terpusat hanya pada guru. Budaya belajar yang dikembangkan adalah keaktifan peserta didik dalam membangun sendiri keingintahuannya, membangun karakter keinginan membantu teman yang kesulitan, serta pemanfaatan waktu yang bisa optimal di kelas karena kegiatan sudah terstruktur.

Pada Edmodo terdapat kegiatan terstruktur untuk setiap pertemuan, sehingga peserta didik mampu mengatur waktu belajar di kelas yang harapannya sejalan dengan mengoptimalkan fasilitas yang ada. Dengan demikian, keaktifan peserta didik dalam membangun sendiri pengetahuannya diharapkan dapat membantu peserta didik untuk lebih lama mengingat dan memahami materi pelajaran. Hasil ini juga sejalan dengan penelitian yang dilakukan oleh Mamentu (2013) dalam penelitiannya yang menyebutkan sebanyak $78,5 \%$ peserta didik meningkat kualitas belajarnya dengan menggunakan bahan ajar $E$ learning. Hasil tersebut dipengaruhi oleh indikator-indikator yang meliputi: kualitas web, penyajian materi, interaksi program, interaksi user, panduan, desain pembelajaran, dan fasilitas E-Learning itu sendiri.

Pengelolaan konten Edmodo yang baik telah menarik dan merangsang minat peserta didik dalam pembelajaran di kelas karena fitur pada Edmodo lebih mampu mengembangkan pengetahuan peserta didik, bervariasi, memberikan suasana yang berbeda, mengembangkan imajinasi dan tidak membuat peserta didik merasa jenuh dalam mengikuti pelajaran. Penekanan penggunaan E-Learning 
Edmodo dalam pembelajaran juga ditekankan Morris \& Matthew (2012) dalam penelitiannya yang mengungkapkan bahwa daya tarik menggunakan LMS adalah metode yang fleksibel dan nyaman dalam memberikan pendidikan online. Sistem tersebut memudahkan guru dan peserta didik dalam pembelajaran mulai persiapan, tahap pelaksanaan, sampai evaluasi. Salah satu LMS yang digunakan adalah Edmodo.

Penggunaan aplikasi E-Learning Edmodo membuat peserta didik berperan lebih aktif dalam memperoleh kesempatan membangun sendiri pengetahuannya sehingga memperoleh pemahaman yang mendalam serta dalam proses pembelajarannya lebih bervariatif seperti mengunggah, mengunduh dan menjawab kuis maupun mendemonstrasikan hasil praktik belajarnya. Penerapan pembelajaran dengan metode Discovery Learning berbantuan aplikasi E-Learning Edmodo juga dapat melatih kemampuan peserta didik dalam memecahkan masalah melalui penemuan yang dilakukan sehingga peserta didik mampu membangun pengetahuan sendiri, mampu menemukan konsep-konsep dari materi pelajaran dan daya ingatan lebih tahan lama. Dengan adanya hal tersebut, proses pembelajaran di kelas menjadi lebih bermakna, yang pada akhirnya berpengaruh pada peningkatan hasil belajar peserta didik, dan memberikan kesempatan kepada peserta didik untuk menyampaikan gagasan, bertanya, melakukan diskusi pendapat dengan anggota kelompok sehingga suasana kelas tidak pasif dan menjadi lebih aktif. Interaksi yang terjadi dalam pembelajaran adalah interaksi multi arah yaitu antara guru dengan peserta didik dan antara sesama peserta didik.

Hasil penelitian ini juga senada dengan penelitian yang dilakukan oleh Sudibjo dan Wasis (2013: 187-190) tentang penggunaan media pembelajaran fisika dengan E-Learning berbasis Edmodo Blog Education yang mengungkapkan keadaan bahwa penggunaan media pembelajaran fisika dengan e-learning berbasis Edmodo Blog Education pada materi pokok Alat Optik, membuat peserta didik termotivasi kuat untuk belajar fisika dan dapat membantu peserta didik untuk meningkatkan hasil belajar peserta didik dalam aspek kognitif.

Berdasarkan analisis data yang telah dilakukan, terdapat perbedaan hasil belajar peserta didik laki-laki dengan perempuan.
Perempuan memiliki rata-rata hasil belajar yang lebih tinggi dibandingkan dengan laki-laki. Perbedaan ini tampak pada dominasi peserta didik perempuan dalam proses pembelajaran. Pada fitur aplikasi Edmodo dapat dilihat aktivitas peserta didik perempuan yang selalu mengomentari tautan postingan materi atau tugas dari guru dibandingkan laki-laki. Perempuan menggunakan komunikasi yang sopan ketika berkomentar pada postingan, menyimpan tugas proyek, dan menjawab kuis di Edmodo dibandingkan peserta didik laki-laki. Pada pembelajaran tanpa bantuan E-Learning Edmodo, peserta didik perempuan lebih antusias memperhatikan tayangan presentasi dibandingkan laki-laki. Ekspresi peserta didik perempuan sebagai respon balik terhadap tayangan presentasi sangat menggugah rasa ingin tahunya sehingga muncul banyak pertanyaan terhadap isi dari tayangan presentasi tersebut. Keaktifan peserta didik perempuan juga tampak dalam proses pembelajaran. Peserta didik perempuan selalu mendominasi proses diskusi, memiliki keberanian saat melakukan presentasi, menyampaikan pendapat dengan lantang dan hasil produk yang dibuatnya memiliki hasil yang lebih baik dibandingkan peserta didik laki-laki.

Temuan penelitian ini senada dengan studi nasional yang dilakukan oleh U.S. Department of Education tahun 2000 pada umumnya peserta didik perempuan yang memiliki kemampuan membaca lebih baik dibandingkan laki-laki. Pada studi nasional yang lain juga mengungkapkan bahwa peserta didik perempuan memperlihatkan prestasi membaca dan keterampilan menulis yang lebih baik (Santrock, 2007). Begitu juga penelitian yang dilakukan oleh Fitriani, dkk (2015), yang menyimpulkan bahwa terdapat pengaruh jenis kelamin terhadap pemahaman konsep Fisika bagi peserta didik kelas XI IPA SMAN 1 Empang.

Perbedaan hasil belajar antar peserta didik berdasarkan jenis kelamin disebabkan oleh perbedaan karakteristik masing-masing peserta didik. Peserta didik perempuan memiliki pendengaran lebih teliti dan lebih lebih sensitif dibanding laki-laki sehingga lebih memahami instruksi yang disampaikan guru. Perempuan lebih baik dalam kecepatan persepsi sehingga lebih peka terhadap pengetahuan baru dan menarik perhatian. Perempuan juga lebih mampu mengingat penempatan obyek dan kata- 
kata sehingga aktif dalam diskusi dan pembuatan produk kerajinan. Hal ini sejalan dengan penelitian yang dilakukan oleh Dupri dan Abduljabar (2015) tentang pengaruh model pembelajaran dan gender terhadap kepedulian sosial peserta didik pada pembelajaran pendidikan jasmani. Hasil penelitiannya menyimpulkan tingkat kepedulian sosial peserta didik perempuan lebih baik daripada peserta didik laki-laki.

Kepercayaan diri perempuan yang lebih baik dibandingkan laki-laki dalam menyelesaikan tugas-tugas belajarnya turut mendukung prestasi pendidikannya. Haralambos dan Horlborn (2004) mengungkapkan perempuan lebih dapat mengembangkan keterampilan berbahasa mereka daripada laki-laki, dan sejak sekolah menjadi sarana untuk mengembangkan keterampilan berbahasa, laki-laki mengalami kemunduran dalam prestasi karena laki-laki kurang memusatkan perhatian pada keterampilan berbahasa.

Interaksi merupakan hubungan timbal balik antara dua variabel yang saling berpengaruh. Situasi dan kondisi proses belajar mengajar berlangsung sangat mempengaruhi suatu metode pembelajaran sehingga guru dapat menentukan metode pembelajaran yang sesuai di lingkungan tersebut agar mendapatkan hasil sesuai tujuan pembelajaran. Hasil penelitian ini menunjukkan tidak ada interaksi antara metode Discovery Learning dengan hasil belajar peserta didik berdasarkan jenis kelamin.

Variabel metode Discovery Learning dan jenis kelamin saling bebas atau tidak saling terkait secara bersama-sama mempengaruhi hasil belajar peserta didik. Keberhasilan peserta didik kelas X SMAN 1 Jepara dalam belajar hanya dipengaruhi oleh penggunaan metode Discovery Learning berbantuan aplikasi Edmodo karena faktor pembelajaran dengan Discovery Learning yang dapat membuat peserta didik menemukan sendiri konsep-konsep dan prinsip-prinsip melalui pemikiran sendiri dan kelebihan pada fitur Edmodo. Begitu dengan keberhasilan peserta didik kelas X SMAN 1 Jepara yang dipengaruhi oleh jenis kelamin disebabkan oleh karakteristik peserta didik perempuan yang lebih unggul dari pada laki-laki.

Penelitian lainnya yang menunjukkan tidak ada interaksi antara metode Discovery Learning dengan jenis kelamin terhadap hasil belajar peserta didik yaitu penelitian yang dilakukan oleh Heong (2011) yang menjelaskan bahwa jenis kelamin, prestasi akademik, dan status sosial ekonomi tidak mempengaruhi kemampuan berpikir siswa. Sejalan dengan itu, hasil penelitian oleh Kusuma (2014) diketahui bahwa tidak ada pengaruh interaksi strategi pembelajaran dengan perbedaan gender terhadap keterampilan metakognitif dan hasil belajar siswa.

Dari beberapa bahasan di atas menunjukkan bahwa hasil penelitian ini masih sejalan dengan penelitian-penelitian terdahulu yang memiliki relevansi topik dan bahasan yang serupa yang peneliti berhasil dapatkan. Meski demikian, perlu dilakukan penelitian serupa di masa-masa mendatang untuk membuktikan teoriteori yang masih berlaku mengingat perkembangan teknologi pembelajaran yang sangat masif.

\section{SIMPULAN}

Penelitian ini menghasilkan beberapa hal sebagai berikut: (1) Pelaksanaan metode Discovery Learning berbantuan aplikasi $E$ Learning Edmodo memuat langkah-langkah: Stimulation, Problem Statement, Data Collection, Data Processing, Verification, dan Generalization, (2) Terdapat perbedaan hasil belajar peserta didik yang menggunakan Discovery Learning berbantuan aplikasi $E$ Learning Edmodo dengan Discovery Learning berbantuan aplikasi presentasi di kelas X SMAN 1 Jepara, (3) Terdapat perbedaan hasil belajar peserta didik laki-laki dengan peserta didik perempuan kelas X SMAN 1 Jepara, dan (4) Tidak ada hubungan antara metode Discovery Learning berbantuan aplikasi dengan hasil belajar peserta didik laki-laki dan perempuan kelas X SMAN 1 Jepara.

\section{DAFTAR RUJUKAN}

Bruner, J. S. 1961. The Act of Discovery. Harvard Ed. Rev. Vol. 31. Hal 21-32.

Chang, C. C., dkk. 2014. "Is Blended eLearning as Measured by an Achievement.

Dupri, \& Abduljabar, Bambang. 2015. Pengaruh Model Pembelajaran Dan Gender Terhadap Kepedulian Sosial Siswa Pada Pembelajaran Pendidikan Jasmani. Edusentris, Jurnal Ilmu Pendidikan dan Pengajaran, Vol. 2 No. 1.

Fitriani, Anita.,Prayogi, Saiful., \& Hidayat, Samsun. 2015. Pengaruh Model Pembelajaran Predict, Observe,Explain, 
Write (Poew) Terhadap Pemahaman Konsep Fisika ditinjau dari Jenis Kelamin Kelas XI IPA SMA Negeri 1 Empang. IKIP Mataram. Jurnal Ilmiah Pendidikan Fisika "Lensa" Vol. 3 No.1.

Haralambos and Holborn. 2004. Sociology: Themes and Perspektives 6th Edtion. London: Harper Collins Publisher.

Heong, Y. M., Othman, W. B., Yunos, J. M., Kiong, T. T., Hassan, R. B., \& Mohamad, M. M. B. 2011. The Level of Marzano Higher Order Thinking Skills among Technical Education Students. International Journal of Social Science and Humanity, Vol. 1 No. 2.

Hu, B.,\& Gollin, K. 2010. "Supporting Casebased Learning Through a Collaborative Authoring System". Information Science Reference, New York: Hershey.

Khan, Zeenath Reza. 2014. Using Innovative Tools to Teach Computer Application to Business Students - A Hawthorne Effect or Successful Implementation Here to Stay. Journal of University Teaching \& Learning Practice. 11 (1): 1-13.

Lie, A. 2013. Social Media in a Content Course for The Digital Natives. Teflin Journal, Vol 24, No 1: 1-2.

Mahmoud, A., 2014. The Effect of Using Discovery Learning Strategy in Teaching Grammatical Rules to first year General Secondary Student on Developing Their Achievement and Metacognitive Skills. International Journal of Innovation and Scientific Research, Vol. 5 No. 2: 146-153.

Mamentu, F. Y. 2013. Pengaruh Penggunaan Media Pembelajaran Online Edmodo Terhadap Hasil Belajar Siswa Kelas XI Pada Mata Pelajaran TIK Di SMAN 1 Tondano. Jurnal Ilmiah Engineering and Education Universitas Negeri Medan, Volume 1, No 4.

Mbati, L., 2013. Online Social Media Applications fot Constructivism and Observational Learning. The International Review of Research in Open.

McDonald, Betty, 2011. Self Assessment and Discovery Learning. Educational Research Information Center.

Morris, M., Balderson, D. \& Matthew, M. 2012. Using an Online Learning Management
System for Coaching. The Journal of Physical Education, Recreation \& Dance, 83.4: 50.

Kusuma, Anindita S. H. M. 2014. Pengaruh Strategi Pembelajaran Reading Questioning and Answering (RQA), Think Pair Share (TPS), RQA Dipadu TPS dan Perbedaan Gender terhadap Keterampilan Bertanya, Kesadaran Metakognitif, Keterampilan Metakognitif, Pembentukan Karakter dan asil Belajar Biologi Siswa Kelas VII SMP Negeri Kota Malang. Tesis tidak diterbitkan, Program Studi Pendidikan Biologi, Program Pascasarjana, Universitas Negeri Malang.

Santrock, J.W. 2007. Remaja. Jakarta: Erlangga. Siemens, G., Tittenberger, P. 2009. Handbook of Emerging Technologies for Learning. Diunduh dari http://elearnspace.org/Articles/HETL.pd f.

Sudibjo, Ari dan Wasis. 2013. Penggunaan Media Pembelajaran Fisika dengan ELearning Berbasis Edmodo Blog Education Pada Materi Alat Optik Untuk Meningkatkan Respons Motivasi dan Hasil Belajar Siswa di SMP Negeri 4 Surabaya. Jurnal Inovasi Pendidikan Fisika UNESA, Vol. 02 No. 03: 187190.

Supardi. 2013. Aplikasi Statistika Dalam Penelitian (Konsep Statistika Yang Lebih Komprehensif). Jakarta: Change Publication.

Suriadhi, Gede,. Tastra, I Dewa Kade., dan Suwatra, Ign. Wayan. 2014. Pengembangan E-Learning Berbasis Edmodo pada Mata Pelajaran IPA Kelas VIII di SMP Negeri 2 Singaraja. Journal Edutech Universitas Pendidikan Ganesha, Volume 2 No. 1. 